\title{
Diagnostic Evaluation of Detrimental Phenomena in High-Power Lithium-Ion Batteries
}

\author{
Robert Kostecki $^{* a}$, Jinglei Lei ${ }^{\mathrm{b}}$, Frank McLarnon ${ }^{\mathrm{a}}$, Joongpyo Shim ${ }^{\mathrm{c}}$, Kathryn Striebel $^{\mathrm{a}}$ \\ Environmental Energy Technologies Division, Lawrence Berkeley National Laboratory, \\ University of California, Berkeley, California 94720, USA
}

\footnotetext{
* Corresponding author. Tel.: +1-510-486-6002; fax +1-510-486-7303,E-mal: r_kostecki@lbl.gov ${ }^{a}$ Electrochemical Society member

${ }^{\mathrm{b}}$ Present address: College of Chemistry and Chemical Engineering, Chongqing University, Chongqing, P. R. China, 400044

${ }^{\mathrm{c}}$ Present address: Kunsan National University, 68 Miryong-dong, Kunsan, Chonbuk 573-701, Republic of Korea.
} 


\begin{abstract}
A pouch-type lithium-ion cell, with graphite anode and $\mathrm{LiNi}_{0.8} \mathrm{Co}_{0.15} \mathrm{Al}_{0.05} \mathrm{O}_{2}$ cathode, was cycled at $\mathrm{C} / 2$ over $100 \%$ depth of discharge (DOD) at ambient temperature. The $\mathrm{LiNi}_{0.8} \mathrm{Co}_{0.15} \mathrm{Al}_{0.05} \mathrm{O}_{2}$ composite cathode was primarily responsible for the significant impedance rise and capacity fade observed in that cell. The processes that led to this impedance rise were assessed by investigating the cathode surface electronic conductance, surface structure, composition, and state of charge at the microscopic level with the use of local probe techniques. Raman microscopy mapping of the cathode surface provided evidence that the state of charge of individual $\mathrm{LiNi}_{0.8} \mathrm{Co}_{0.15} \mathrm{Al}_{0.05} \mathrm{O}_{2}$ particles was nonuniform despite the deep discharge at the end of cell testing. Current-sensing atomic force microscopy imaging revealed that the cathode surface electronic conductance diminished significantly in the tested cells. Loss of contact of active material particles with the carbon matrix and thin film formation via electrolyte decomposition not only led to $\mathrm{LiNi}_{0.8} \mathrm{Co}_{0.15} \mathrm{Al}_{0.05} \mathrm{O}_{2}$ particle isolation and contributed to cathode interfacial charge-transfer impedance but also accounted for the observed cell power and capacity loss.
\end{abstract}

Keywords: Li-ion battery, $\mathrm{LiNi}_{0.8} \mathrm{Co}_{0.15} \mathrm{Al}_{0.05} \mathrm{O}_{2}$ cathode, surface conductivity, Raman microscopy, current-sensing AFM. 


\section{Introduction}

High-power Li-ion cells with graphite anodes and $\mathrm{LiNi}_{0.8} \mathrm{Co}_{0.15} \mathrm{Al}_{0.05} \mathrm{O}_{2}$ cathodes that were cycled and stored at elevated temperatures showed significant impedance rise and capacity fade $[1,2]$. Impedance measurements of the cell components carried out with a LiSn reference electrode indicated that the $\mathrm{LiNi}_{0.8} \mathrm{Co}_{0.15} \mathrm{Al}_{0.05} \mathrm{O}_{2}$ cathode is primarily responsible for the observed cell power loss at elevated temperatures [3], similar to the $\mathrm{LiNi}_{0.8} \mathrm{Co}_{0.2} \mathrm{O}_{2}$ cathode [4]. Systematic experiments with model pouch-type lithium-ion cells, with graphite anodes and $\mathrm{LiNi}_{0.8} \mathrm{Co}_{0.15} \mathrm{Al}_{0.05} \mathrm{O}_{2}$ cathodes, which were cycled at $\mathrm{C} / 2$ over different ranges of DOD and at different temperatures, demonstrated that the decline in cell performance, both capacity fade and impedance rise, was strongly dependent on temperature and the span of the cell state of charge (SOC) during cycling [5].

X-ray diffraction spectroscopy measurements failed to detect noticeable changes in the bulk structure of tested $\mathrm{LiNi}_{0.8} \mathrm{Co}_{0.15} \mathrm{Al}_{0.05} \mathrm{O}_{2}$ cathodes [1,5]. Possible causes of the increase in cathode impedance include the formation of an electronic and/or ionic barrier at the cathode surface $[6,7,8]$. Because the surface of the composite electrodes is not homogeneous and typically consists of an oxide, two types of carbon additive, and a binder, suitable instrumental techniques must be used to provide lateral resolution comparable to the size and morphology of electrode surface features.

Ins itu and ex situ application of non-invasive and non-destructive microscopies and spectroscopies, including Raman, fluorescence spectroscopy, SEM, and AFM to characterize physico-chemical properties of the electrode/electrolyte interface at nonometer 
resolution provide unique insight into the mechanism of specific chemical and electrochemical processes that may be responsible for the cell degradation. An innovative application of Raman micro-spectroscopy to generate local surface composition images (at submicron lateral resolution) of positive and carbon negative electrodes in Li-ion cells was already reported $[9,10,11,12]$. The extraordinary potential of Raman micro-spectroscopy was demonstrated by in-situ acquisition of space- and time-resolved spectra from a thin operating Li-ion battery $[13,14]$ and by in-situ studies of dynamic aspects of $\mathrm{Li}^{+}$ intercalation-deintercalation at the scale of a single micrometer-size oxide or graphite particle in the composite electrode $[15,16]$ or single graphite or $\mathrm{LiMn}_{2} \mathrm{O}_{4}$ particle electrodes embedded into selected substrates $[17,18,19,20]$.

This work presents an example of this methodology used in post-test analysis of interfacial phenomena on the composite $\mathrm{LiNi}_{0.8} \mathrm{Co}_{0.15} \mathrm{Al}_{0.05} \mathrm{O}_{2}$ cathodes. The results of this study allow us to correlate changes of the surface structure, electronic properties composition, and/or SOC of the composite cathodes with the increase of the cathode interfacial charge-transfer impedance, which accounts for the observed cell power and capacity loss.

\section{Experimental}

Diagnostic evaluations were carried out with a pouch Li-ion cell, which consisted of a $\mathrm{LiNi}_{0.8} \mathrm{Co}_{0.15} \mathrm{Al}_{0.05} \mathrm{O}_{2}$ cathode, a synthetic graphite anode, $1.2 \mathrm{M} \mathrm{LiPF}_{6}+$ ethylene carbonate + ethyl-methyl carbonate (EC/EMC) electrolyte, and a Celgard ${ }^{\circledR} 2300$ separator. Details of 
the cell construction, assembl,y and formation were reported previously [5,21]. Cycle-life testing was carried out with $\mathrm{C} / 2$ charging to $4.1 \mathrm{~V}$, a taper charge at 4.1 to a minimum current of $\mathrm{C} / 20$ (or a maximum of 2 hours), and a $\mathrm{C} / 2$ discharge to a potential limit of $3.0 \mathrm{~V}$. At the end of cycling, the cell was fully discharged at C/25 to $3.0 \mathrm{~V}$ (100\% DOD), and the discharged cell was disassembled in an Ar glovebox. The cathode was soaked in DEC overnight and dried in the glovebox prior to diagnostic evaluations.

We carried out comparative studies of a fresh cathode with samples of cathodes removed from that cell. All cathode samples were soaked in EMC for 30 minutes after removal from Li-ion cells inside an argon-filled glove box. The samples were placed in an airtight cell prior to being removed from the glove box and further investigated.

A Raman microscope system "Labram" (ISA Groupe Horiba) was used to analyze and map the cathode surface structure and composition. The excitation source was an internal He-Ne $(632 \mathrm{~nm}) 10 \mathrm{~mW}$ laser. The power of the laser beam was adjusted to $0.1 \mathrm{~mW}$. The diameter of the laser beam at the sample was $\sim 1.2 \mu \mathrm{m}$. Raman images were collected in autofocus mode. Individual Raman spectra were processed and deconvoluted using the PeakFit 4.0 commercial software package. Fluorescence images of the cathodes were obtained in the 527-691 nm spectral range in response to $514 \mathrm{~nm}$ excitation.

We used current-sensing atomic force microscopy (CSAFM) to image the surface of the $\mathrm{LiNi}_{0.8} \mathrm{Co}_{0.15} \mathrm{Al}_{0.05} \mathrm{O}_{2}$ cathodes in constant-force contact mode under a controlled He 
atmosphere. The microscope consisted of a Picoscan Molecular Imaging scanning probe microscope coupled with a ThermoMicroscopes Inc. AFM electronic controller. The Si atomic force microscope (AFM) tips were coated with a thin conductive layer of $\mathrm{W}_{2} \mathrm{C}$. All CSAFM experiments were performed at constant oxide-tip voltage difference. A conductance image, which represents oxide-tip current variations during scanning at a given oxide-tip voltage difference, was produced simultaneously with a conventional topographic image.

\section{Results}

The $\mathrm{C} / 2$ discharge capacity vs. cycle history for the cell tested in this study is shown in Figure 1 . The cycle coulombic efficiency averaged $99.93 \%$, which led to a $70 \%$ capacity fade during C/2 cycling after 1000 cycles [5]. Low-rate capacity measurements at C/25 showed only $40 \%$ capacity fade, which indicates that impedance changes in the cell are responsible for a significant fraction of the observed capacity fade at $\mathrm{C} / 2$. Post-test electrochemical diagnostic studies of the electrodes revealed that the $\mathrm{C} / 25$ capacity of the anode, after being harvested from the cycled cell, showed essentially identical capacity to the fresh anode in a half-cell measurement. On the other hand, the tested $\mathrm{LiNi}_{0.8} \mathrm{Co}_{0.15} \mathrm{Al}_{0.05} \mathrm{O}_{2}$ cathode displayed an irreversible $\mathrm{C} / 25$ capacity loss of about $27 \%$ with reference to the fresh cathode. The loss of cycleable Li, most likely due to solvent

reduction on the anode, was found to be partially responsible for the observed cell capacity loss. However, it appears that the cathode degradation is the most important contributor to the cell failure mechanism during the long-term cycling. X-ray diffraction spectra of the cycled cathode (not shown here) indicate that the active material is still intact, i.e., no new 
phases or signs of structural damage was observed.

Figure 2A shows a typical ex situ Raman microscopy spectrum of the composite $\mathrm{LiNi}_{0.8} \mathrm{Co}_{0.15} \mathrm{Al}_{0.05} \mathrm{O}_{2}$ cathode. It consists of two groups of bands: a broad maximum centered at $\sim 510 \mathrm{~cm}^{-1}$, characteristic for $\mathrm{LiNi}_{0.8} \mathrm{Co}_{0.15} \mathrm{Al}_{0.05} \mathrm{O}_{2}$ oxide, and two peaks at $\sim 1350$ and $\sim 1600 \mathrm{~cm}^{-1}$. The band at $510 \mathrm{~cm}^{-1}$ consists of two Raman-active vibrations characteristic for $\mathrm{LiNi}_{0.8} \mathrm{Co}_{0.15} \mathrm{Al}_{0.05} \mathrm{O}_{2}$ oxide, which crystallizes in the rhombohedral layered structure of $\alpha-\mathrm{NaFeO}_{2}(\mathrm{R} 3 \mathrm{~m})$. The (G) band at $1600 \mathrm{~cm}^{-1}$ corresponds to the $\mathrm{E}_{2 \mathrm{~g}}$ active mode of graphite [22]. Te (D) band at $\sim 1350 \mathrm{~cm}^{-1}$ is assigned to the $A_{1 \mathrm{~g}}$ mode and is associated with the breakage of symmetry that occurs at the edges of graphite sheets. The carbon $\mathrm{G}$ and $\mathrm{D}$ bands represent graphite and carbon black conducting additives, which are the carbonaceous components of the composite cathode. A semi-quantitative surface analysis of the cathode surface composition was carried out by Raman mapping of a 52x75 $\mu \mathrm{m}$ section of the cathode surface at $0.7 \mu \mathrm{m}$ resolution (Figure 2B). The optical image of the mapped area is shown in Figure 2C. The $1.2 \mu \mathrm{m}$ diameter laser beam was able to probe and map individual $\mathrm{LiNi}_{0.8} \mathrm{Co}_{0.15} \mathrm{Al}_{0.05} \mathrm{O}_{2}$ agglomerates, which were about one order of magnitude larger than the laser beam and consisted of smaller sub-micron primary crystallites. Thousands of Raman spectra were deconvoluted, analyzed, and displayed as color-coded points on the composition image map in which the saturations of red, blue, and green colors are proportional to the integrated areas under the respective Raman bands of $\mathrm{LiNi}_{0.8} \mathrm{Co}_{0.15} \mathrm{Al}_{0.05} \mathrm{O}_{2}$, acetylene black, and graphite, respectively. The resultant color for each location corresponds to the local surface concentration ratio of the components of the 
composite cathode. The mapping and spectral analysis procedure was described in detail in $[4]$.

Interestingly, the spectra of the of $\mathrm{LiNi}_{0.8} \mathrm{Co}_{0.15} \mathrm{Al}_{0.05} \mathrm{O}_{2}$ particles in the tested cathode vary significantly as a function of location on the cathode surface. Figure 3 shows Raman signatures of three separate oxide particles that were selected and investigated by Raman microscopy (see Figure 2B). The spectra shown in Fig. 3 display features characteristic for fully discharged (1), partially charged (2), and fully charged (3) $\mathrm{Li}_{1-}$ ${ }_{x} \mathrm{Ni}_{0.8} \mathrm{Co}_{0.15} \mathrm{Al}_{0.05} \mathrm{O}_{2}$ material. The spectra of all three particles are dominated by two bands at 475 and $553 \mathrm{~cm}^{-1}$, characteristic for $\mathrm{Li}_{1-x} \mathrm{Ni}_{0.8} \mathrm{Co}_{0.15} \mathrm{Al}_{0.05} \mathrm{O}_{2}$ oxide and associated with vibrations characteristic of the $\mathrm{NiO}_{2}$ lattice. An example of a deconvoluted $\mathrm{Li}_{1-\mathrm{x}} \mathrm{Ni}_{0.8} \mathrm{Co}_{0.15} \mathrm{Al}_{0.05} \mathrm{O}_{2}$ spectrum is shown in the Fig. 3 insert. The symmetry of these vibrations in $\mathrm{Li}_{1-\mathrm{x}} \mathrm{Ni}_{0.8} \mathrm{Co}_{0.15} \mathrm{Al}_{0.05} \mathrm{O}_{2}$ is somewhat distorted by the presence of electronic and coordination structures originating from weak Li-O bonds. The bands tend to broaden and the 475/553 band ratio varies significantly with increasing lithium content in the lattice. Such a change of the band profiles in the vibrational spectra is usually attributed to a change of the $a$ and $c$ parameters of the $\mathrm{Li}_{1-\mathrm{x}} \mathrm{Ni}_{0.8} \mathrm{Co}_{0.15} \mathrm{Al}_{0.05} \mathrm{O}_{2}$ crystal lattice with a different lithium content. The level of lithiation can be monitored by observing and quantifying changes of $475 / 553$ peak parameters, i.e., peak widths and peak intensity ratio. Therefore, we can conclude that the cathode surface SOC is highly non-uniform and varies between individual grains of active material from fully discharged through partially charged to fully charged, even though the cell was fully discharged at the end of cell testing. 
To quantify the amount of charged active material still present at the surface of the composite cathode, the Raman spectra that constitute the color-coded map shown in Fig. 2B were deconvoluted. Each individual spectrum was examined and deconvoluted to determine the SOC of the active material at each location. Figure 4 shows a color-coded pattern of fully discharged (orange) and partially or fully charged (red) $\mathrm{Li}_{1-}$ ${ }_{x} \mathrm{Ni}_{0.8} \mathrm{Co}_{0.15} \mathrm{Al}_{0.05} \mathrm{O}_{2}$. The white areas correspond to locations where spectral characteristics and SOC of the $\mathrm{Li}_{1-\mathrm{x}} \mathrm{Ni}_{0.8} \mathrm{Co}_{0.15} \mathrm{Al}_{0.05} \mathrm{O}_{2}$ could not be probed because the oxide was covered by a thick layer of carbon additives. The micro-Raman surface SOC map of the cathode from the cycled cell clearly indicates that lithium content in the exposed bare oxide grains varies substantially at different locations. Interestingly, primary oxide particles within the same agglomerate remain at different SOC. These observations suggest that kinetic barriers at the micro-scale exist within the composite cathode and were likely contributors to non-uniform current density and charge distribution in the tested cathode.

Figure 5 shows CSAFM images of surface conductance (right-hand panel) and topography (left-hand panel) of a representative $5 \times 5 \mu \mathrm{m}$ region of the composite $\mathrm{LiNi}_{0.8} \mathrm{Co}_{0.15} \mathrm{Al}_{0.05} \mathrm{O}_{2}$ cathode surface at $1.0 \mathrm{~V}$ tip-sample voltage difference from (A) a fresh cell, and (B) the cathode from the cycled cell. The surface morphology images of both cathodes reveal no significant changes in the cathode surface topography in tested cells. The surface conductance image of the cathode from a fresh cell exhibits areas of mostly high electronic conductance (black areas) and only a few insulating regions (white areas). 
Highly conductive graphite and acetylene black additives constitute are primarily responsible for the excellent electronic properties observed at the cathode surface. The insulating areas on the cathode surface are most likely associated with the presence of nonconductive PVDF binder, SEI layers, and deep cavities between particles of the electrode components. The conductance image of the cathode from the tested cell shows a substantial increase of surface resistance. Large areas of the cathode surface became insulating except for a few locations, which still display very good (black areas) or fair (gray) electronic conductivity. This result is similar to our earlier studies of the $\mathrm{LiNi}_{0.8} \mathrm{Co}_{0.2} \mathrm{O}_{2}$ and $\mathrm{LiNi}_{0.8} \mathrm{Co}_{0.15} \mathrm{Al}_{0.05} \mathrm{O}_{2}$ cathodes $[4,12]$, which showed a complete lack of conductivity of the cathode surface, consistent with either loss of contact of particles at the electrode surface with the rest of the electrode, or the presence of a nonconductive film of polycarbonates and/or $\mathrm{LiF}, \mathrm{Li}_{x} \mathrm{PF}_{y}, \mathrm{Li}_{x} \mathrm{PF}_{y} \mathrm{O}_{z}$-type compounds [23].

\section{Discussion}

The Raman microscopy surface SOC maps and CSAFM surface conductivity images of the cycled cathode indicate that non-uniform performance at the microscale of the $\mathrm{LiNi}_{0.8} \mathrm{Co}_{0.15} \mathrm{Al}_{0.05} \mathrm{O}_{2}$ particles in composite cathodes is one of the key symptoms of cell performance degradation. The non-uniform SOC of the cathode active material directly implies that some parts of the composite electrode charge and discharge at different rates, as compared to the average current density. Consequently, the electrode local current distribution is highly non-homogeneous, which may lead to local overcharge or overdischarge and thereby trigger other detrimental phenomena such as electrolyte decomposition, structural changes in the oxide, and/or mechanical disintegration of oxide 
secondary particles. Importantly, the particles at different SOC should eventually equilibrate, unless substantial ionic or electronic resistances exist between particles and/or the $\mathrm{Al}$ current collector. This is consistent with our earlier studies [12, 24], in which we demonstrated that the inconsistent kinetic behavior of the individual oxide particles was attributed to degradation of the electronically conducting matrix in the composite cathode upon testing. These local phenomena are responsible for uneven performance of the cathode and lead to overall electrode impedance increase and irreversible electrode capacity loss, which contribute to the mechanism of lithium-ion cell failure. Carbon additive rearrangement in portions of the tested $\mathrm{LiNi}_{0.8} \mathrm{Co}_{0.15} \mathrm{Al}_{0.05} \mathrm{O}_{2}$ cathodes and/or thin film formation on the surfaces of carbon and oxide particles is closely linked with the observed isolation of oxide active material. We did not detect the presence of any thick surface film that could inhibit lithium-ion diffusion into or out of the oxide. Therefore, we postulate that the loss of electronic contact between primary particles of $\mathrm{LiNi}_{0.8} \mathrm{Co}_{0.15} \mathrm{Al}_{0.05} \mathrm{O}_{2}$ with the current collector is most likely the origin of the observed non-uniform electrochemical performance of the active material at the microscale and loss of the electrode's electrochemical performance. The primary particles could be in poor electronic contact in the original material [12], but it is likely that they deteriorate even further during cell cycling/aging due to repeated mechanical stress. If the carbon additives form a dense uniform matrix, which provides good electronic contact between the Al current collector and primary crystallites within the active material agglomerates, full utilization of the active material and low electrode impedance can be achieved. However, the spectroscopic data indicate that the distribution of carbon additives within the composite cathodes changes substantially upon cell cycling/storage. Also, a thin film of electrolyte 
decomposition products $\left(\mathrm{LiF}, \mathrm{Li}_{x} \mathrm{PF}_{y}, \mathrm{Li}_{x} \mathrm{PF}_{y} \mathrm{O}_{z}\right)$ can influence the contact resistance between the electrode components. Consequently, the resulting local impedance increase leads to uneven current and potential distribution and excessive current densities at various locations and accelerated degradation of the active material because of local overchargeoverdischarge. This chain of detrimental phenomena leads eventually to a substantial loss of electrochemical capacity and power in the composite cathodes despite the fact that cathode active material bulk remains essentially unchanged after testing in Li-ion cells.

\section{Acknowlegment}

This research was supported by the Director, Office of Energy Research, Office of Basic Energy Sciences, Chemical Sciences Division of the U.S. Department of Energy under Contract No. DE-AC03-76SF00098 and the Assistant Secretary for Energy Efficiency and Renewable Energy, Office of FreedomCAR and Vehicle Technologies of the U.S. Department of Energy under Contract No. DE-AC02-05CH11231. 


\section{References}

1. FY 2002 Progress Report for Energy Storage Research and Development, http://www.eere.energy.gov/vehiclesandfuels/resources/fcvt_publications.shtml

2. X. Zhang, P. N. Ross, Jr., R. Kostecki, F. Kong, S. Sloop, J. B. Kerr, K. Striebel, E. J. Cairns and F. McLarnon, J. Electrochem. Soc., 148, 463 (2001).

3. D.P. Abraham. S.D. Poppen, A.N. Jansen, J. Liu, D.W. Dees, Electrochimica Acta, 49, $4763(2004)$

4. R. Kostecki, F. McLarnon, Electrochem. Solid State Lett., 5, A164 (2002)

5. K.A. Striebel, J. Shim, E.J. Cairns, R. Kostecki, Y.-J. Lee, J. Reimer, T.J. Richardson, P.N. Ross, X. Song, G. V. Zhuang, J. Electrochem. Soc., 151 A857 (2004)

6. D. P. Abraham, R. D. Twesten, M. Balasubramanian, J. Kropf, D. Fischer, J. McBreen, I. Petrov, K. Amine, J. Electrochem. Soc., 150, A1450 (2003)

7. G.V. Zhuang, G. Chen. J. Shim, X. Song, P.N. Ross, T.J. Richardson, J. Power Sources, 4, 293 (2004)

8. S.W. Song, G.V Zhuang, P.N. Ross, J. Electrochem. Soc. 151, A1162 (2004)

9. J.-C. Panitz, P. Novák, J. Power Sources, 97-98, 174 (2001)

10. J.-C. Panitz, P. Novák, O. Haas, Appl. Spectrosc., 55, 1131 (2001)

11. R. Kostecki, F. McLarnon, J. Power Sources, 119-121, 550 (2003)

12. R. Kostecki, F. McLarnon, Electrochem. Solid State Lett., 7, A380 (2004)

13. I. Rey, J.C. Lassègues, P. Baudry, H. Majastre, Electrochim. Acta, 43, 1539 (1998)

14. Y. Luo, W.-B. Cai, D.A. Scherson, Electrochem. Solid-State Lett., 7, E1 (2004)

15. P. Novák, J.-C. Panitz, F. Joho, M. Lanz, R. Imhof, M. Coluccia, J. Power Sources, 90, $52-58(2000)$ 
16. D. Ostrovskii, F. Ronci, B. Scrosati, P. Jacobsson, J. Power Sources, 94, 183 (2001)

17. Y. Luo, W.-B. Cai, D.A. Scherson, Electrochem. Solid-State Lett., 4, A101 (2001)

18. Y. Luo, W.-B. Cai, D.A. Scherson, J. Electrochem. Soc., 149, A1100 (2002)

19. Totir, D, A.; Scherson, D.A., Electrochem. Solid State Lett. 3, 263 (2000)

20. Dokko, K.; Shi, Q.; Stefan, I.C.; Scherson D.A., J. Phys. Chem. B, 46, 12549 (2003)

21. J. Shim, R. Kostecki, T. Richardson, X. Song, K.A. Striebel, J. Power Sources, 112, $222(2002)$

22. F. Tunistra; J.L. Koenig, J.L. J. Chem. Phys., 53, 1126 (1970)

23. A. M. Andersson, D. P. Abraham, R. Haasch, S. MacLaren, J. Liu, and K. Amine, J. Electrochem. Soc., 149, A1358 (2002)

24. J Lei, F. McLarnon, R. Kostecki, J. Phys. Chem. B., 109(2), 952-957 (2005) 


\section{Figure Captions}

Figure1. $\mathrm{C} / 2$ discharge capacity of a $\mathrm{LiNi}_{0.8} \mathrm{Co}_{0.15} \mathrm{Al}_{0.05} \mathrm{O}_{2} / 1.2 \mathrm{M} \mathrm{LiPF}$, EC/EMC/Mag-10 pouch cell under a 100\% DOD cycling regimen.

Figure 2. (A) A typical Raman spectrum of the composite $\mathrm{LiNi}_{0.8} \mathrm{Co}_{0.15} \mathrm{Al}_{0.05} \mathrm{O}_{2}$ electrode, (B) $52 \times 75 \mu \mathrm{m}$ Raman microscope image of the composite $\mathrm{LiNi}_{0.8} \mathrm{Co}_{0.15} \mathrm{Al}_{0.05} \mathrm{O}_{2}$ cathode from the cycled cell. The image was collected at $0.7 \mu \mathrm{m}$ resolution. The intensities of red, blue, and green colors correspond to the integrated band intensities of $\mathrm{LiNi}_{0.8} \mathrm{Co}_{0.15} \mathrm{Al}_{0.05} \mathrm{O}_{2}$, and D, G carbon bands of each spectrum, respectively, (C) optical image of the mapped area.

Figure 3. Raman microscope spectra of three individual $\mathrm{LiNi}_{0.8} \mathrm{Co}_{0.15} \mathrm{Al}_{0.05} \mathrm{O}_{2}$ particles in the tested cathode. The insert shows an example of deconvoluted $\mathrm{Li}_{1-\mathrm{x}} \mathrm{Ni}_{0.8} \mathrm{Co}_{0.15} \mathrm{Al}_{0.05} \mathrm{O}_{2}$ spectrum.

Figure 4. Color-coded pattern of fully discharged (orange) and partially or fully charged (red) $\mathrm{Li}_{1-\mathrm{x}} \mathrm{Ni}_{0.8} \mathrm{Co}_{0.15} \mathrm{Al}_{0.05} \mathrm{O}_{2}$. The $\mathrm{SOC}$ map was derived from the Raman microscopy image of the composite $\mathrm{LiNi}_{0.8} \mathrm{Co}_{0.15} \mathrm{Al}_{0.05} \mathrm{O}_{2}$ cathode that is shown in Fig. $2 \mathrm{~B}$.

Figure 5. CSAFM images of surface conductance (right-hand panel) and topography (lefthand panel) of a $5 \times 5 \mu \mathrm{m}$ region of the composite $\mathrm{LiNi}_{0.8} \mathrm{Co}_{0.15} \mathrm{Al}_{0.05} \mathrm{O}_{2}$ cathode surface at 1.0 V tip-sample voltage difference: (A) fresh cell; (B) cathode from the cycled cell. 


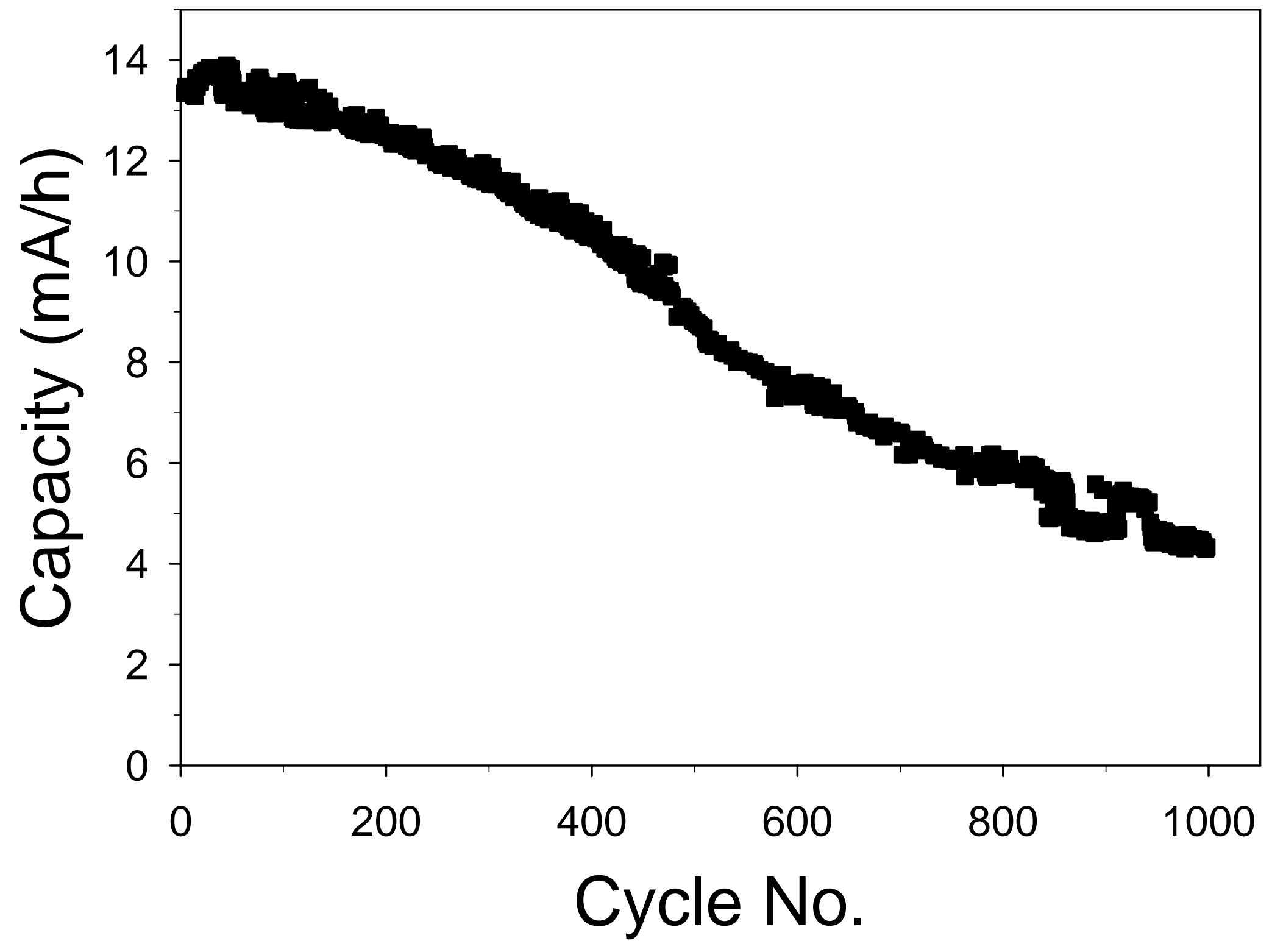




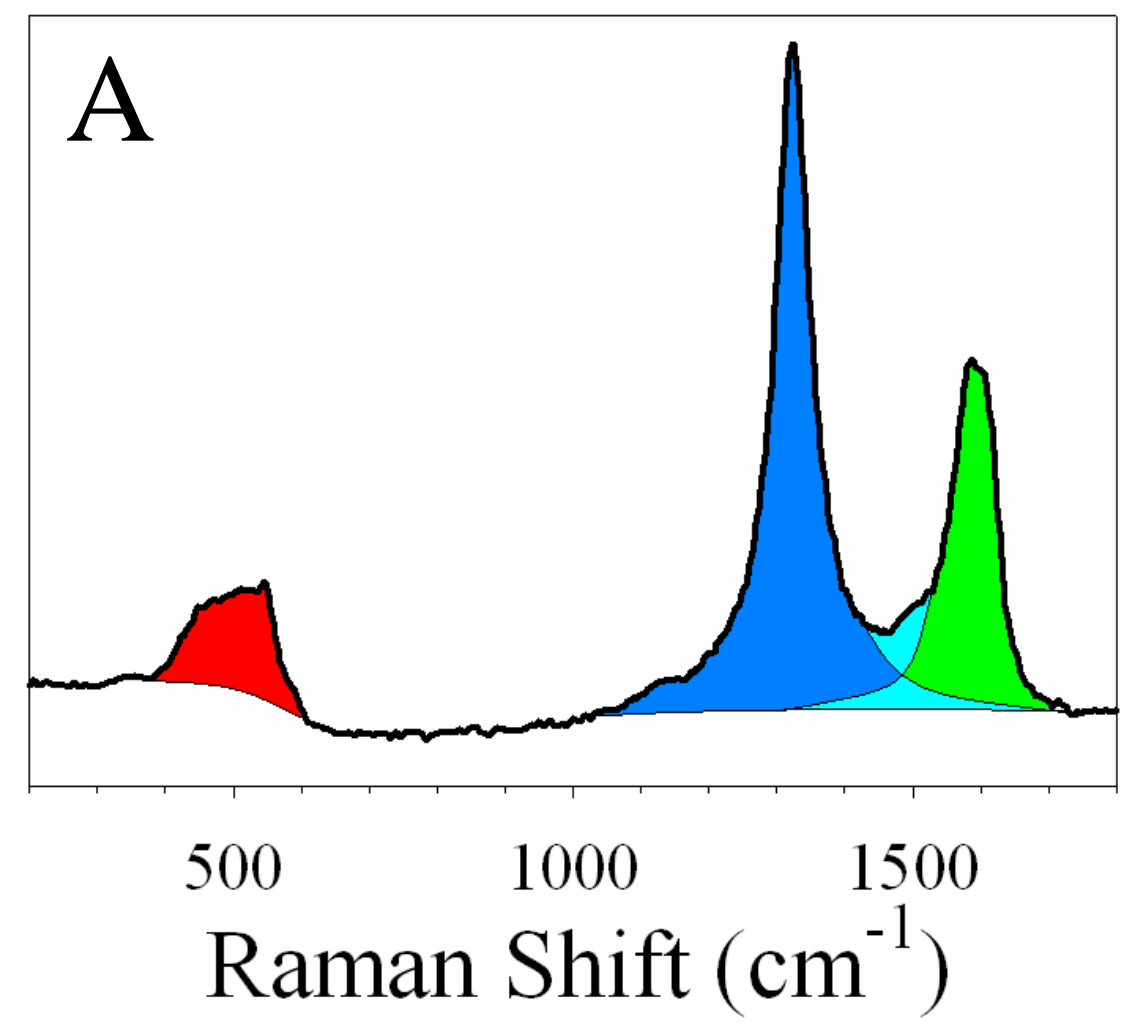

B

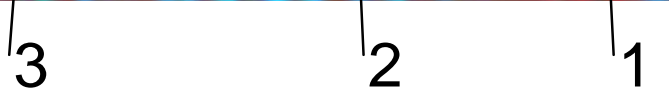

- $\mathrm{LiNi}_{0.8} \mathrm{Co}_{0.15} \mathrm{Al}_{0.05} \mathrm{O}_{2}$

- graphite

acetylene black 


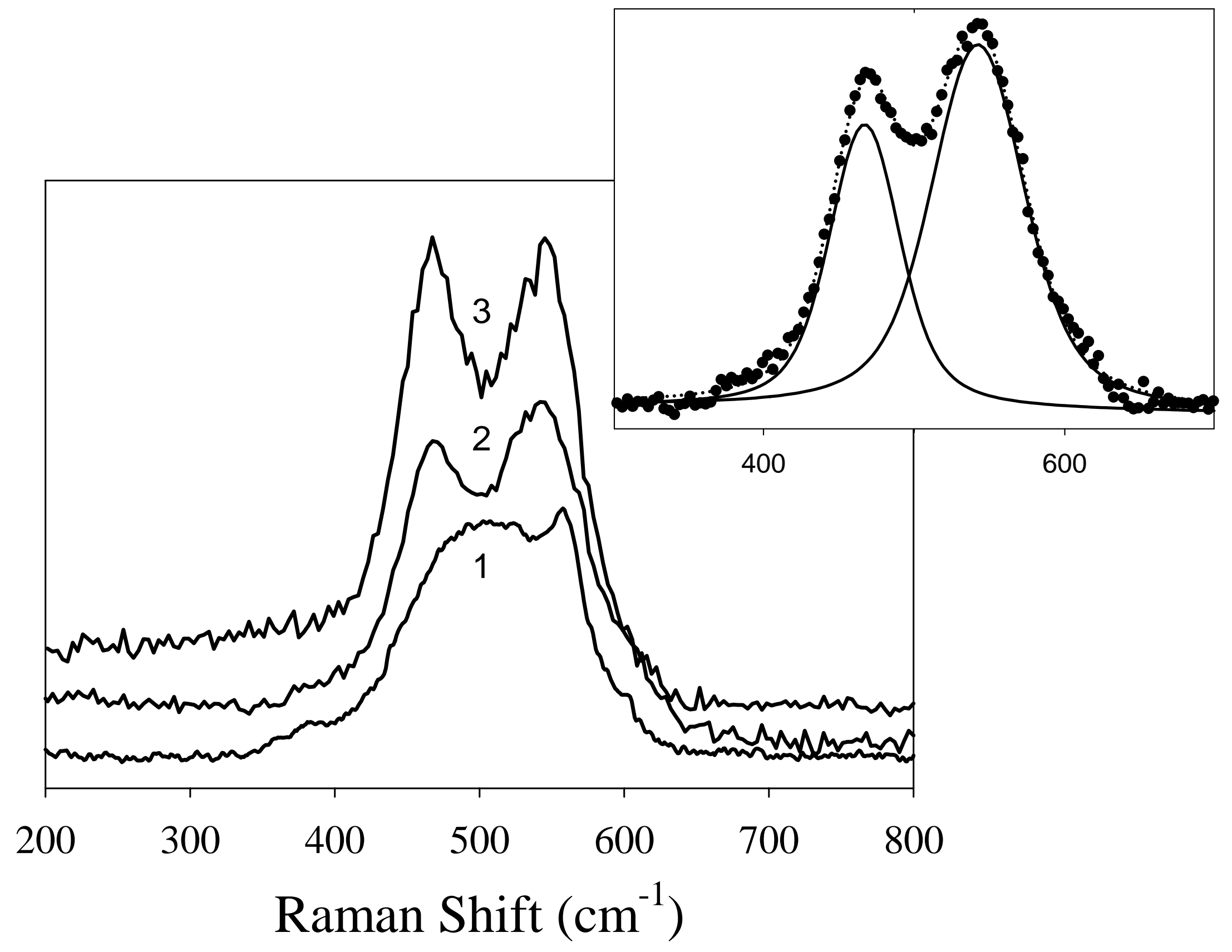




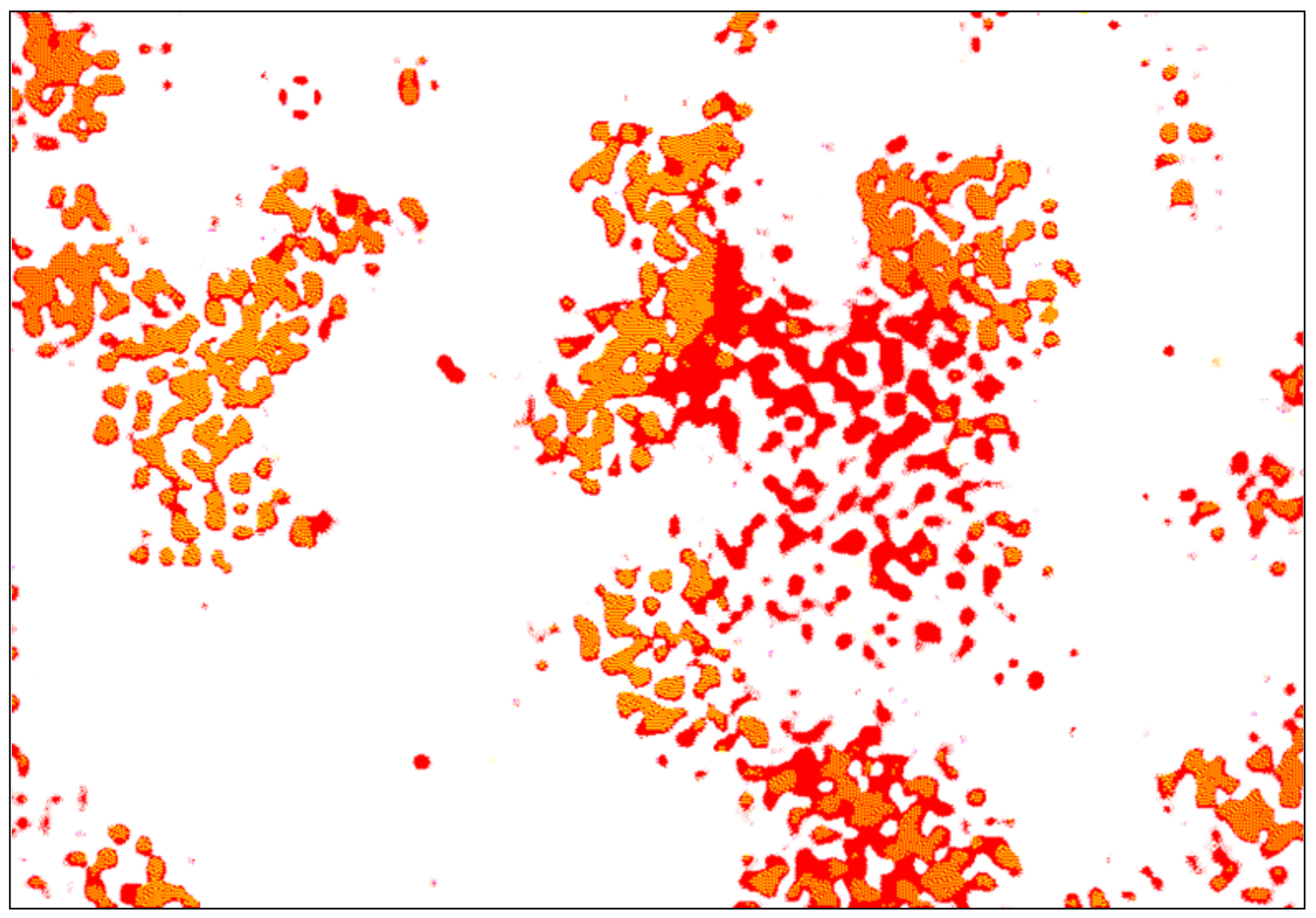



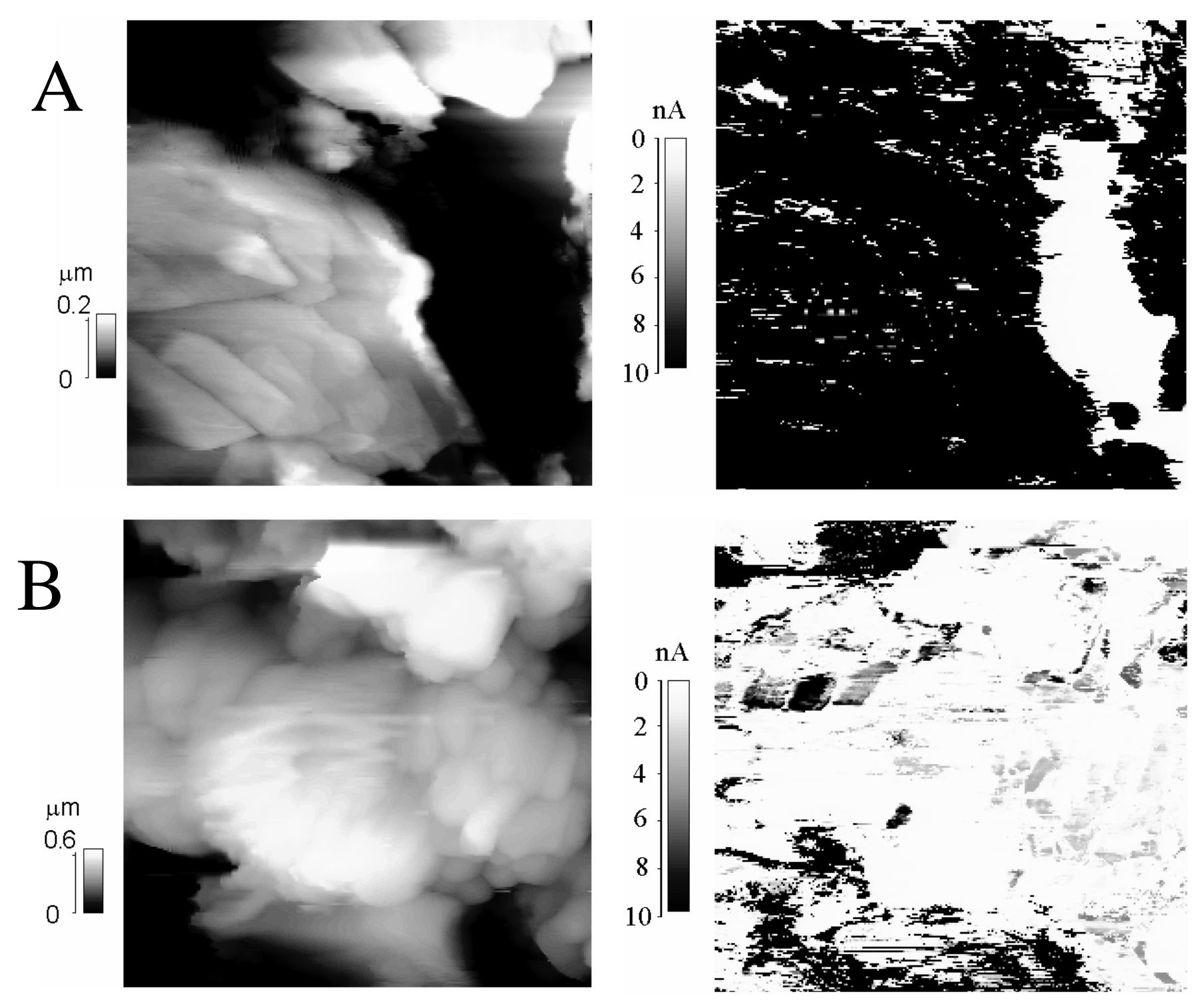